\title{
Phytoplasma and virus detection in commercial plantings of Vitis vinifera cv. Merlot exhibiting premature berry dehydration
}

\author{
José Tomás Matus \\ Departamento de Genética Molecular y Microbiología \\ Facultad de Ciencias Biológicas \\ Pontificia Universidad Católica de Chile \\ Alameda 340, Casilla 114-D \\ Santiago, Chile \\ Tel: 5626862893 \\ Fax: 5622225515 \\ E-mail: tomas.matus@gmail.com

\section{Andrea Vega} \\ Facultad de Ciencias Biológicas \\ Pontificia Universidad Católica de Chile \\ Alameda 340, Casilla 114-D \\ Santiago, Chile \\ Tel: 5626862893 \\ Fax: 5622225515 \\ E-mail: avegac@uc.cl

\section{Rodrigo Loyola} \\ Facultad de Ciencias Biológicas \\ Pontificia Universidad Católica de Chile \\ Alameda 340, Casilla 114-D \\ Santiago, Chile \\ Tel: 5626862893 \\ Fax: 5622225515 \\ E-mail: loyola.munoz@gmail.com
}

\section{Carolina Serrano}

Facultad de Ciencias Biológicas

Pontificia Universidad Católica de Chile

Alameda 340, Casilla 114-D

Santiago, Chile

Tel: 5626862893

Fax: 5622225515

E-mail: clserran@uc.cl

\section{Soledad Cabrera}

Facultad de Ciencias Biológicas

Pontificia Universidad Católica de Chile

Alameda 340, Casilla 114-D

Santiago, Chile

Tel: 5626862893

Fax: 5622225515

E-mail: cabrera.sole@gmail.com

\author{
Patricio Arce-Johnson* \\ Facultad de Ciencias Biológicas \\ Pontificia Universidad Católica de Chile \\ Alameda 340, Casilla 114-D \\ Santiago, Chile \\ Tel: 5626862893 \\ Fax: 5622225515 \\ E-mail: parce@bio.puc.cl
}

Financial support: Grape and Wine Chilean Consortium Project $N^{\circ}$ 05CTE01-03, 07Genoma01 and Millennium Nucleus for Plant Functional Genomics (P06-009-F).

\footnotetext{
\# These authors contributed equally to this work.
}

*Corresponding author 
Keywords: berry shrinkage, Candidatus phytoplasma mali, late ripening, over ripened, pedicel necrosis, phloem, water transport.

Abbreviations: GFLV: grapevine fanleaf virus

GLRaV: grapevine leaf roll-associated virus

GVA: grapevine virus A

GVB: grapevine virus B

PBD: premature berry dehydration

RSPaV: rupestris stem pitting-associated virus
A new and devastating physiological disorder of Vitis vinifera cv. Merlot was recently reported, known as premature berry dehydration (PBD), which is characterized by plant growth reduction, induction of general senescence and pedicel necrosis in the fruit, causing significant reductions in vineyard production. The causes of this disease remain unclear and previous reports suggest that it may be associated with phloem disruption and water provision. For this reason, any factor causing phloem disturbances could cause an important change in the berry water status. As some micro-organisms have been reported to disrupt phloem flow, we analyzed the occurrence of phytoplasma and viruses in commercial vineyards presenting PBD. In this study, a phytoplasma was detected by electron microscopy and nested PCR while virus infections were diagnosed by RT-PCR in samples collected during two growing seasons. The presence of phytoplasma only in samples from grape plants with PBD suggests that this pathogen may be one of the causal agents of this disorder. We suggest that the influence of other factors, such as virus infections, agronomic handling and environmental conditions also modulate berry dehydration. This is the first study at the microscopic and molecular levels that correlates phytoplasma presence with PBD.

In Chile, a new physiological disorder has recently been observed in cv. Merlot vineyards, causing as much as 20 to $80 \%$ reductions in yield (Moreno et al. 2004). This phenomenon, known as premature berry dehydration (PBD), can be observed throughout berry ripening, and is characterized by berries with high acidity and sugar concentrations and low colour at the usual harvest period. Berries may shrink up to the point of being useless for vinification. Although berries aren't able to import sufficient sugars from the plant, they experience an increase in soluble solids concentration as a result of the rapid loss of water. Possible causes for cv. Merlot PBD are diverse. Most studies have been directed at the irrigation and water management of soils, although a combination of factors may be responsible. The effect of water deficit does not explain PBD on its own but can accelerate the problem (Moreno et al. 2004).

Chilean summer temperatures and the common practice of reduced irrigation usually increases dehydration episodes and wines obtained from surviving plants present an unbalanced sweet/acid ratio and poor organoleptic complexity.

This disorder has also been observed in other cultivars of $V$. vinifera. In the Syrah cultivar, the principle cause appears to be cuticle disruption leading to high transpiration rates (Rogiers et al. 2004) and xylem back flow (Tyerman et al. 2004). In these cases, weight loss was unrelated to the irrigation regime, seasonal differences and root stocks. However, this behaviour may be cultivar dependent, as post veraison cv. Shiraz showed reduced hydraulic resistivity at the proximal end of the pedicel, whereas post veraison cv.
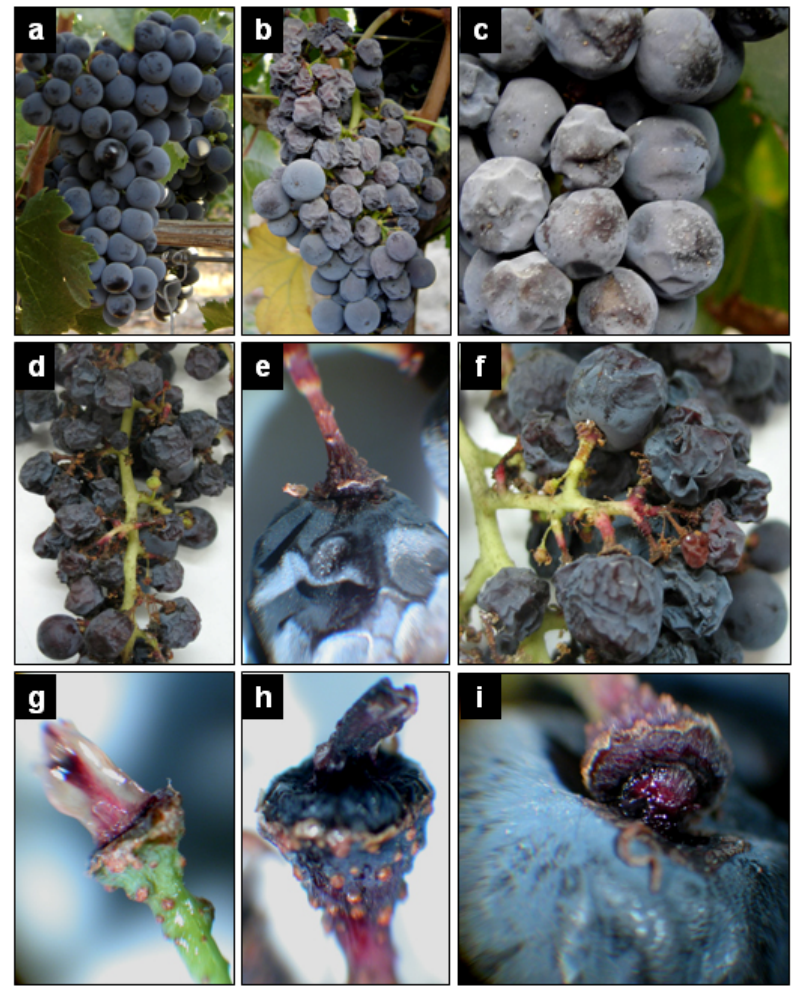

Figure 1. Premature berry dehydration (PBD) symptoms. (a) Cv. Merlot healthy cluster.

(b) Premature dehydrated berries in field conditions may be observed randomly in each plant and cluster.

(c) Berry skin wrinkling is evident on the surface of dehydrated berries.

(d) No bunch stem necrosis is observed in PBD.

(e-f) Anthocyanin pigmentation is present in the terminal bunch stem and necrosis is observed in the pedicels.

(g) Healthy pedicel.

(h) Details of a necrotic PBD pedicel.

(i) Berries suffering PBD are only loosely attached to the pedicel. 
Phytoplasma and virus detection in commercial plantings of Vitis vinifera cv. Merlot exhibiting premature berry dehydration

Table 1. Primer sequences used to detect simultaneously 11 viruses by means of RT-PCR.

\begin{tabular}{|c|c|c|c|c|}
\hline Virus & Acronym & Forward primer (5'-3') & Reverse primer (5'-3') & $\begin{array}{l}\text { Product } \\
\text { size (bp) }\end{array}$ \\
\hline $\begin{array}{c}\text { Arabis Mosaic } \\
\text { Virus }\end{array}$ & ArMV & GCCCACGACTTTTCTAATCAAGA & CTAAACGCCTGTCGGAGTAATAA & 295 \\
\hline $\begin{array}{l}\text { Grapevine leafroll } \\
\text { associated virus } 1\end{array}$ & GLRaV1 & TTCAGCTTACTGTGGTCTCTATGG & GCTTCATTTGGAGTCACGAATG & 109 \\
\hline $\begin{array}{l}\text { Grapevine leafroll } \\
\text { associated virus } 2\end{array}$ & GLRaV2 & TACACCTCTCGCAATGTTTATCAC & GACCGCTAATCTTCACCGTTAT & 139 \\
\hline $\begin{array}{l}\text { Grapevine leafroll } \\
\text { associated virus } 3\end{array}$ & GLRaV3 & TAACCACCATGAAGTTCATAGGG & GCATTAGAAACAGCTTCGAATACGA & 274 \\
\hline $\begin{array}{l}\text { Grapevine leafroll } \\
\text { associated virus } 8\end{array}$ & GLRaV8 & AGAAGAGAGGGATTGGATTGGAAT & AGTCTTCTCGGTGGCTTAAATTC & 172 \\
\hline $\begin{array}{c}\text { Grapevine fanleaf } \\
\text { virus }\end{array}$ & GFLV & TTCTTTACTTGCCCTTATGGGC & CAAAATGCCAGTCGCATTTCTC & 254 \\
\hline $\begin{array}{c}\text { Grapevine Fleck } \\
\text { virus }\end{array}$ & GFkV & TTCACAACACAATCCAGAAGGATAC & СTCTTCATGAACATGACCGTGG & 262 \\
\hline $\begin{array}{c}\text { Grapevine } \\
\text { rootstock stem } \\
\text { lesion associated } \\
\text { virus }\end{array}$ & GRSLaV & CAATTGAGTTTTGGTCAGCCTG & ACGGCAAAAATACCATTCACAC & 317 \\
\hline Grapevine virus $A$ & GVA & ATGCAAAGGTTCTTAGGTAGTCTC & GTACTTGTACGATTCCTCCGTCA & 327 \\
\hline Grapevine virus $B$ & $G V B$ & TAGTGATGGGTTGTTTGATTACCAT & TGCTCTCTTGGATAGCTCAGATA & 355 \\
\hline $\begin{array}{c}\text { Rupestris stem } \\
\text { pitting-associated } \\
\text { virus }\end{array}$ & RSPaV & AGCTCTCAAGGCATTAGTAGACT & СCAATGCCСTTTCTACTGACAAC & 384 \\
\hline
\end{tabular}

Chardonnay, which does not present berry shrinkage, did not.

It has been suggested that water and solute supply into grape berries becomes phloem-dominant after veraison (Greenspan et al. 1994). Nevertheless, recent studies demonstrate that the xylem is still functional after this period (Chatelet et al. 2008). Any factor causing phloem interruption after veraison could cause a significant change in berry water provision, with consequences for fruit growth and ripening. Among these factors, some microorganisms have being reported to disrupt phloem flow.

The incidence of pathogens in commercial cv. Merlot grapevines displaying PBD disorder has not been previously reported. Virus infections in grapevines might result in effects such as diminished fruit yields and reduced quality of the wine produced. Different virus-infected cultivars experience reductions in chemical parameters such as juice soluble solid content, berry skin anthocyanin concentrations and wine sensory evaluation parameters (Mannini et al. 1998; Cabaleiro et al. 1999). As an example, Grapevine Leaf Roll associated Viruses (GLRaV) may induce symptoms including downward rolling of leaves and increased or decreased anthocyanin accumulation in leaves or berries, respectively. In grapevine, diseases caused by phytoplasmas (some of which are known as grapevine yellows) may generate similar symptoms as viruses (Martini et al. 1999; Angelini et al. 2001; Boudon-Padieu, 2003; Lee et al. 2004). These prokaryotes from the Mollicute Classdiverged from Gram-positive bacteria and suffered cell wall loss and genome reduction (Lee et al. 2000). Phytoplasmas have been detected in Chilean vineyards (Herrera and Madariaga, 2003) and in other regions of the world, producing downward rolling of leaves, reduced yield, high acid and low sugar contents of infected clusters (Boudon-Padieu, 1999). 

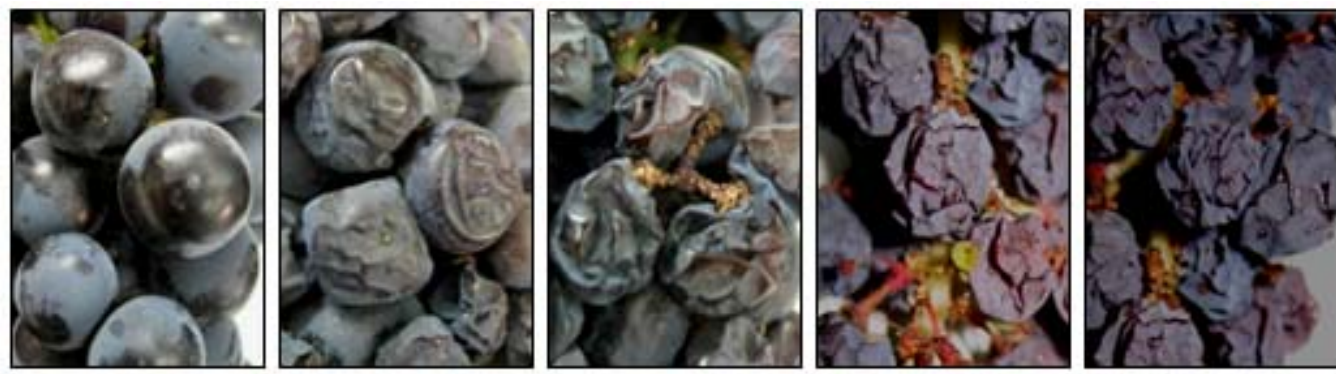

\begin{tabular}{|l|c|c|c|c|c|}
\hline & Healthy & Initial PBD & $\begin{array}{c}\text { Advanced } \\
\text { PBD }\end{array}$ & $\begin{array}{c}\text { Extreme } \\
\text { PBD }\end{array}$ & $\begin{array}{c}\text { Over ripened } \\
\text { shrinkage }\end{array}$ \\
\hline PBD degree & $\mathbf{0}$ & $\mathbf{1}$ & 2 & 3 & - \\
\hline Berry weight $(\mathrm{g})$ & $>190$ & $\mathbf{1 6 0 - 1 7 0}$ & $100-150$ & $<90$ & $<170$ \\
\hline Extracted vol $(\mathbf{m l})$ & $>90$ & $40-70$ & $<30$ & - & $<70$ \\
\hline${ }^{\circ}$ Brix & $24-26$ & $27-28$ & $29-30$ & $>30$ & $>27$ \\
\hline $\mathrm{pH}$ & $3.3-3.5$ & $<3,3$ & $<3,3$ & $<3.3$ & $>3.5$ \\
\hline Ant. & $>80$ & $<60$ & $<60$ & $<60$ & $>80$ \\
\hline
\end{tabular}

Figure 2. Classification of the different degrees of PBD in cv Merlot, based on all samples collected at commercial harvest. Data from over-ripened grape clusters are included as an out-group to differentiate both types of berry shrinkages. Berry weight and extracted volume was measured for a set of 200 berries. Total anthocyanins are expressed as absorbance at $520 \mathrm{~nm}$ per gram of fresh weight, as described by Boss et al. (1996).

Both phytoplasma and viruses are able to affect fruit development and ripening, possibly as a result of phloem disruption. This blockage could hinder berry sugar accumulation and delay ripening. Since cv. Merlot plants with PBD present some of these symptoms, we determined in this study whether viruses and phytoplasma were present and associated with PBD in grapevines from commercial vineyards. We also described the main characteristics of this physiological disorder.

\section{MATERIALS AND METHODS}

\section{Sample collection and preparation}

During the 2005-2006 and 2006-2007 growing seasons, lignified shoots, leaves and grape bunches from Vitis vinifera $\mathrm{cv}$. Merlot vines, both healthy and those exhibiting PBD, were analyzed from eight commercial vineyards located in four viticultural valleys in Chile (Aconcagua, Maipo, Rapel and Curicó). Photographs were taken in the field and, using a Nikon SMZ800 Stereoscopic Microscope, in the laboratory. Shoots, bunch stems and pedicels were prepared for microscopic analysis and pathogen detection.

Grape berry ripening parameters were analyzed at commercial harvest from ten clusters per vineyard (five healthy and five showing PBD). Berries from a single plant for each date were grouped and a subset of 200 berries was weighed and then crushed for measuring juice volume, $\mathrm{pH}$ and total soluble solids using a hand held refractometer. Anthocyanin concentration was measured as described by Boss et al. (1996). A $0.5 \mathrm{~g}$ sample of 10-20 ground berry skins was added to $1 \mathrm{ml}$ of methanol and the anthocyanins were extracted for $1 \mathrm{hr}$ at $-20^{\circ} \mathrm{C}$. Grape tissue was centrifuged at $10,000 \mathrm{~g}$ for $15 \mathrm{~min}$ at $4^{\circ} \mathrm{C}$, and $5 \mu \mathrm{l}$ of the extract diluted in $1 \mathrm{~mL}$ in methanol and $1 \%(\mathrm{v} / \mathrm{v}) \mathrm{HCI}$, from which an A520 $\mathrm{nm}$ reading was recorded.

Berries, bunch stems and leaves from healthy and PBD vines were frozen in liquid nitrogen and stored separately at $-80^{\circ} \mathrm{C}$ until molecular studies for pathogen detection were conducted.

\section{Optical and electronic microscopy}

Shoots, peduncles and pedicels from healthy and dehydrated cv. Merlot vines were prepared for optical and electronic microscopy. For optical microscopy analysis, samples were prepared according to the method described by O'Brien and McCully (1981) with additional modifications. Samples of approximately 0.2 to $0.5 \mathrm{~cm}$ were fixed in FAA solution (formaldehyde $5 \%$, acetic acid $5 \%$, ethanol $63 \%$ and $\mathrm{H}_{2} \mathrm{O} 27 \%$ ) during $1 \mathrm{hr}$. Then, they were dehydrated in a series of absolute ethanol, with an increase of $20 \%$ at each stage. Samples were vacuum infiltrated and shrunk gradually in Paraplast. Samples were sectioned using a rotary microtome and stained with $0.5 \%$ $(w / v)$ safranine and $0.5 \%(w / v)$ Fast Green. Sections were observed and photographed using a Nikon E800 Eclipse Optical Microscope.

For electronic microscopy analysis, samples were fixed in cacodylate-buffer ( $\mathrm{pH} 7.2$ ) and 3\% glutaraldehyde for $3 \mathrm{hrs}$ at room temperature according to Lartey et al. (1997). Samples were washed in cacodylate buffer for $1 \mathrm{hr}$, dehydrated in an acetone series $(50 \%, 70 \%, 95 \%$ and 
$100 \%)$ and embedded in freshly prepared Embed 812 (EM Sciences, Fort Washington, PA). After overnight polymerization at $60^{\circ} \mathrm{C}$, thin sections $(70-80 \mathrm{~nm})$ were made using a Sorvall MT2-B ultramicrotome. Samples were stained with uranyl acetate (Epstein and Holt, 1963) followed by lead citrate (Reynolds, 1963) and examined under a Philips Tecnai 12 Transmission Electron Microscope.

\section{Phytoplasma detection via nested PCR}

Genomic DNA from leaves and raquis (the grape scaffold) from healthy and dehydrated Merlot was isolated from approximated $1.5 \mathrm{~g}$ of fresh tissue using a phytoplasma enrichment procedure as described by Ahrens and Seemuller (1992). A CTAB DNA extraction method (using CTAB 2\% (w/v), NaCl $1.42 \mathrm{M}$, EDTA $20 \mathrm{mM}$, Tris-HCl $100 \mathrm{mM} \mathrm{pH} \mathrm{8,0,} \mathrm{PVP40} \mathrm{2 \%} \mathrm{(w/v)} \mathrm{and} \beta$-mercaptoethanol $0,5 \%$ ) was then used as described by Ausubel et al (1990). DNA was RNAse treated $(10 \mathrm{mg} / \mathrm{ml})$ and incubated at $37^{\circ} \mathrm{C}$ for $30 \mathrm{~min}$.

PCR reactions $(50 \mu \mathrm{l})$ contained $40 \mathrm{ng}$ of genomic DNA, $1 \mathrm{X}$ Buffer (Invitrogen), $25 \mathrm{mM} \mathrm{MgCl}, 1 \mu \mathrm{M}$ of each primer, $200 \mu \mathrm{M}$ dNTPs, and 0.6 units of Taq polymerase (Invitrogen). Three primer pairs were used to amplify the DNA of phytoplasma: The universal primer pair P1 (5'AAGAGTTTGAT CCTGGCTCAGGATT-3') (Deng and Hiruki, 1991) and P7 (5'-CGTCCTTCATCGGCTCTT-3') (Schneider et al. 1995) were used in direct PCR and two other primer pairs 16R758F GTCTTTACTGACGCTGAGGC-3') /16R1232R (5'CTTCAGCTACCCTTTGTAAC-3') (Gibb et al. 1995) and fU5 (5'-CGGCAATGGA GGAAACT-3')/ rU3 (5'TTCAGCTACTCTTTGTAACA-3') (Lorenz et al. 1995) were used in a nested PCR to amplify DNA from the same samples. Products of DNA amplifications with the primer pair P1 / P7 (1.8 kb) were diluted (1:20) and used as templates in nested PCR with the primer pairs 16R758F/16R1232R and fU5/rU3. The same thermal conditions were used for direct and nested primers as follows: a first hot start step of $94^{\circ} \mathrm{C}$ for $10 \mathrm{~min} ; 35$ cycles of $94^{\circ} \mathrm{C}, 30 \mathrm{sec} ; 55^{\circ} \mathrm{C}, 45 \mathrm{sec} ; 72^{\circ} \mathrm{C}, 30 \mathrm{sec}$; followed by a final extension period of $72^{\circ} \mathrm{C}$ for $10 \mathrm{~min}$. In both direct and nested PCR, the PCR amplification products were analyzed by $1 \%$ agarose gel electrophoresis, stained in ethidium bromide and visualized and photographed on a UV transilluminator.

\section{Virus detection}

RT-PCR was performed in order to test the presence of eleven viruses in healthy or dehydrated cv. Merlot samples from all vineyards evaluated. Total RNA from leaves was isolated according to Reid et al. (2006), using a CTABSpermidine extraction buffer. Following precipitation with $\mathrm{LiCl}$, the RNA pellet was redissolved in Qiagen RNeasy Buffer and purified according to the manufacturer's instructions (Qiagen). Optimal PCR primers were designed for amplification of the genomic viral sequences (Table 1). Such design was performed using the MUMMER software (Kurtz et al. 2004) that identifies all sequences which do not present any homology among the viral genomes selected. PCR reactions $(25 \mu \mathrm{l})$ contained $1-10 \mathrm{ng}$ of cDNA, $2.5 \mathrm{mM} \mathrm{MgCl}_{2}, 400 \mu \mathrm{M}$ dNTPs, $250 \mathrm{nM}$ of each primer, $0.16 \mathrm{mg} / \mathrm{ml} \mathrm{BSA,} 0.1 \%(\mathrm{v} / \mathrm{v})$ Triton X-100, and 0.1 units $/ \mu$ of Taq platinum polymerase (Invitrogen). The thermocycling regime used was as follows: a first hot start step of $94^{\circ} \mathrm{C}$ for $10 \mathrm{~min} ; 30$ cycles of $94^{\circ} \mathrm{C}, 45 \mathrm{sec} ; 60^{\circ} \mathrm{C}, 1$ $\min ; 72^{\circ} \mathrm{C}, 2 \mathrm{~min}$; followed by a final extension period of $72^{\circ} \mathrm{C}$ for $10 \mathrm{~min}$.

\section{RESULTS}

\section{PBD symptom description}

General symptoms in commercial cv. Merlot grapevines with PBD differed in each vineyard and valley. It was possible to observe a progressive decline in growth; shoot length varied between $0.70 \mathrm{~m}$ and $1.20 \mathrm{~m}$ in the most affected vineyards and early leaf abscission, short internodes and advanced senescence were observed. In some cases the degree of dehydration was so advanced that

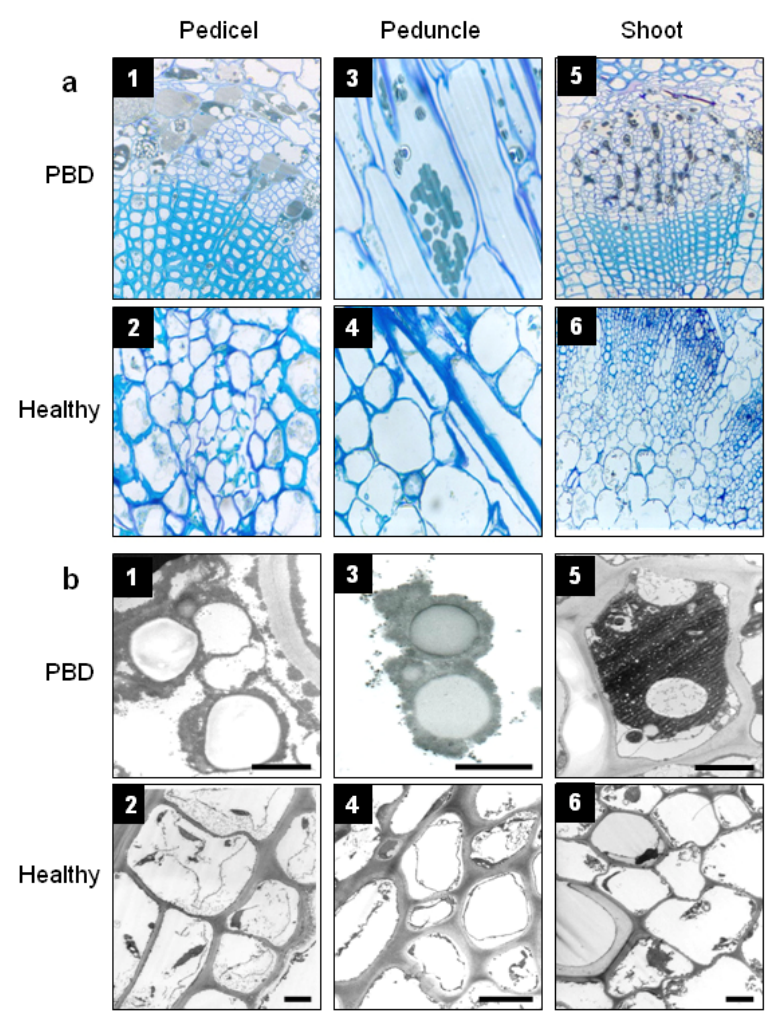

Figure 3. (a) Optical and (b) Electron microscopy analysis of pedicels, peduncles and shoots from plants exhibiting PBD. Ovoid and spherical bodies can be seen in the cytoplasm of phloem vascular system cells. Samples from healthy plants are included as negative controls. Viral particles were also observed (data not shown). a1: 20X, a2-4: 40X, a56: 10X. Bars: $1 \mu \mathrm{m}$ (b1, b3, b5), $5 \mu \mathrm{m}$ (b2, b4, b6). 
almost all grapes were shriveled and had fallen to the ground. Virus-like symptoms such as leaf rolling or pigmented leaves sometimes accompanied berry dehydration.

A variety of different symptoms were associated with this disorder, including chlorosis, leaf deformation, pedicel necrosis, as well as dehydrated clusters. Such clusters were observed on vines grown in either a north-south or an eastwest orientation. Plants were heterogeneously affected throughout the vineyard and not all clusters were dehydrated in a same plant.

PBD symptoms were characterized at berry ripening (Figure 1). Dehydrated clusters had a wrinkled cuticle compared with healthy grapes (Figure 1b; Figure 1c). Additionally, the peduncle remained green, whereas the pedicel acquired a red pigmentation (anthocyanin) and necrotic zones appeared (Figure 1d; Figure 1f). Throughout berry ripening, these necrotic regions extended towards the grape cluster affecting the brush structure (Figure 1h), leading ultimately to a disconnection between the plant and the grape bunch (Figure 1i).

It was possible to classify different degrees of PDB. This classification was based on measurements of berry weight, soluble solid content, $\mathrm{pH}$, anthocyanin accumulation in berry skins and the volume of extracted juice (Figure 2). Data from over-ripened grape clusters (late-ripening associated disorder) was incorporated as an external group to differentiate both types of berry shrinkages. Lateripening parameters belonged to a cv. Cabernet Sauvignon field left in the plant for one additional month compared to the commercial harvest date. Plants with PBD symptoms from a single vineyard showed sequentially each of these degrees, although their severity could depend on other biotic pathogens or cultural practices that may increase stress in the plant. Interestingly, plants collected in the same vineyard showed the same degree of PBD.

\section{Detection of phytoplasma and viruses in PBD samples}

The methods used to verify the presence of these pathogens included molecular-based tools and microscopic techniques. Examination of sections of pedicel, peduncle and lignified shoots from PBD plants by optical microscopy revealed the presence of mycoplasma-like structures in the phloem cells, as shown in Figures 3a5; Figure $3 \mathrm{a} 3$ and Figure 3a1, respectively.

Examination of ultrathin sections of pedicel, peduncle and shoots by transmission electron microscopy (TEM) revealed numerous ovoid bodies localized in the phloem cells (Figure 3b). These bodies have been described in sieve tubes and companion cells of plants infected with phytoplasma (Siddique et al. 1998; Rudzinska-Langwald and Kaminska, 1999; Christensen et al. 2004; Christensen et al. 2005). These possible phytoplasmas were restricted to
Table 2. Incidence of viruses in commercial vineyards. The percentage of PBD and PBD-free plants from which viruses were detected by RT-PCR is shown.

\begin{tabular}{|c|c|c|}
\hline Virus & PBD & PBD-free \\
\hline ArMV & 0 & 0 \\
\hline GLRaV1 & 0 & 20 \\
\hline GLRaV2 & 0 & 0 \\
\hline GLRaV3 & 12.5 & 20 \\
\hline GLRaV8 & 75 & 100 \\
\hline GFLV & 50 & 40 \\
\hline GFkV & 0 & 0 \\
\hline GRSLaV & 0 & 0 \\
\hline GVA & 0 & 20 \\
\hline GVB & 12.5 & 20 \\
\hline RSPaV & 12.5 & 0 \\
\hline
\end{tabular}

the phloem tissue in pedicel, peduncle and shoots and were typically between 150 to $400 \mathrm{~nm}$ in diameter (Herrera and Madariaga, 2003; Chang et al. 2004). No phytoplasmas were detected in healthy plants (Figure 3B).

To verify the presence and the molecular identity of the possible phytoplasma in dehydrated plants, a nested PCR assay was conducted. The universal primer pair 16R758F /16R1232R amplified a $0.5 \mathrm{~kb}$ fragment of the 16S rRNA phytoplasma gene. This product was sequenced and comparative analysis of $16 \mathrm{~S}$ rRNA gene sequences revealed $99.6 \%$ similarity to Candidatus phytoplasma mali, $99.4 \%$ to Candidatus phytoplasma pyri, $93.9 \%$ to Periwinkle witches-broom phytoplasma and Chile grapevine yellows phytoplasma, $93.7 \%$ to VK grapevine yellows phytoplasma and $93.1 \%$ to Candidatus phytoplasma australiense. Nested PCR amplification with the other primer pair fU5/rU3 amplified $850 \mathrm{bp}$ fragments for all samples with dehydrated symptoms.

During monitoring of commercial vineyards, 40 grapevine samples were tested to detect phytoplasma infection by nested PCR as described previously. All samples showing PBD symptoms amplified the phytoplasma sequence. However, phytoplasmas were present in $14.3 \%$ of samples collected from asymptomatic cv. Merlot samples. In addition, asymptomatic samples from cv. Pinot noir were also found to harbour phytoplasma. 
Furthermore, filamentous virus particles were detected by electron microscopy in some of the PBD samples (data not shown). To establish if these pathogens were related to the dehydration disorder, RT-PCR was performed with virus specific primers (Table 1) in samples from all vineyards. A summary of the results is shown in Table 2. Using this analysis, GLRaV-3, GLRaV-8, GFLV, RSPaV and GVB were detected, but not in all PBD-derived samples. Interestingly, plants without symptoms were greatly infected with GLRsV-1, GLRsV-3, GLRsV-8, GFLV, GVA and GVB. This analysis showed that virus infections were not associated exclusively with PBD.

\section{DISCUSSION}

In this work the PBD disorder affecting commercial plantings of Vitis vinifera cv. Merlot was evaluated in Chile. Among the symptoms, diverse processes were altered, such as vegetative growth, and particularly fruit development. Sugars concentrate while the berry gradually dehydrates, although it seems this increase is not able to produce a higher level of anthocyanins. Instead, berries present less colour and higher acidity, two signs which suggest that the berry cluster is not developing properly or ripening enough until harvest. The necrosis in the pedicel is of particular interest. It is possible to differentiate this

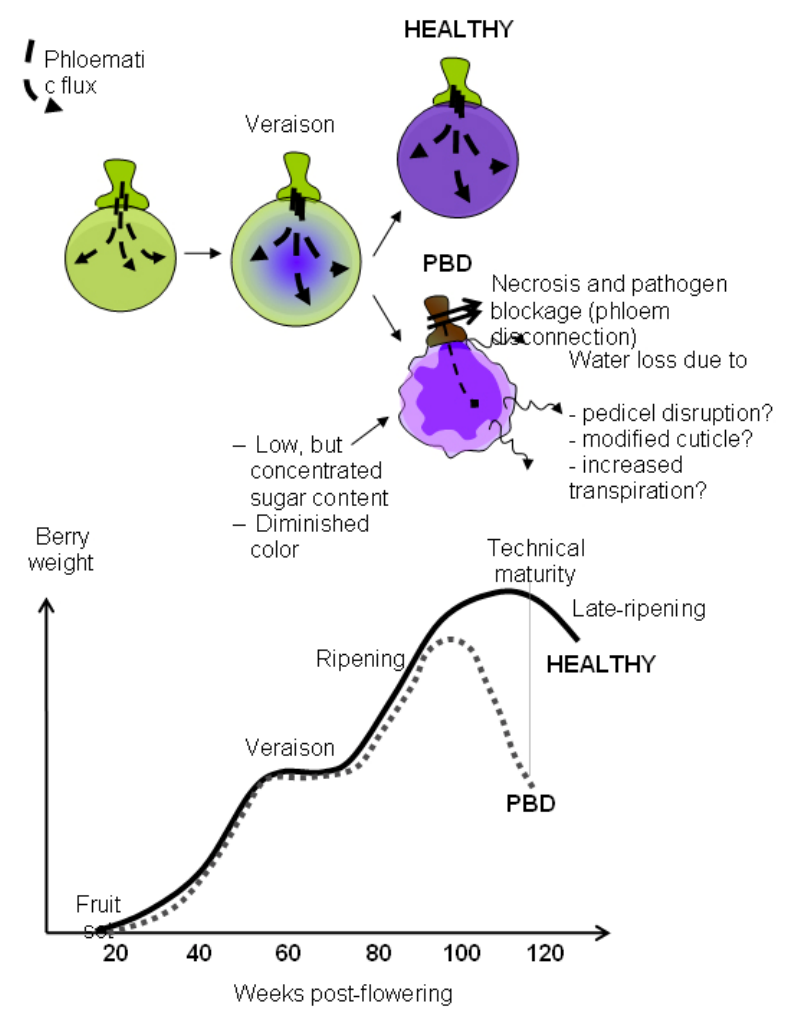

Figure 4. Model explaining berry ripening in premature dehydrated bunches. Phloem fibers are blocked within the pedicel and brush areas. The effects on berry weight can be seen post-veraison (refer to Results section for details). disorder from bunch stem necrosis (BSN) which has been described in table grapes and is characterised by necrosis in all raquis and not exclusively in the pedicels.

The survey performed in commercial vineyards of $\mathrm{cv}$ Merlot detected the presence of phytoplasmas and viral pathogens from the Closterovirus and/or Nepovirus genuses in plants presenting PBD, although only phytoplasma were present in all dehydrated samples. These pathogens may interrupt photo-assimilate and water transport through the phloem. Furthermore, phytoplasma infection can cause anatomical aberrations such as extensive phloem necrosis and excessive formation of phloem tissue, resulting in swollen veins (Lee et al. 2000). Thus, they can be responsible for physically impairing translocation of water, solutes and photoassimilates in the phloem. As this is the most functional translocation vessel after veraison, nutrient supply to the berry diminishes drastically.

In this study, there is an association between the presence of phytoplasma, verified by electron microscopy and nested PCR, with PBD. However, virus infections may increase the severity of this disorder, as viruses also spread through the phloem to many organs, thus affecting general nutrient distribution in the plant, shifting the sink-source balance (Herbers et al. 2000; Hofius et al. 2001).

The fact that we were able to detect these pathogens in asymptomatic plants may indicate that a very low, but detectable titre may be present prior to the development of PBD. As phytoplasma cannot be cultured in vitro, Koch's postulates cannot be demonstrated. However, the presence of phytoplasma only in samples from grape plants with PBD, both by electron microscopy and nested PCR, is a strong indication that the phytoplasma may be one of the causal agents of this disorder.

It has been previously shown that virus-infected plants suffer an important decrease in colour of the juice produced (Borgo and Angelini, 2002). Cell sugar transport can directly affect colour in berry skins as there is a genetic relationship between sugar content and anthocyanin biosynthesis. This relationship has been found in a broad of plant species, including grape (Vitrac et al. 2000). Grape flavonoid biosynthetic genes have been found to possess "sucrose boxes" in their promoters (Gollop et al. 2001; Gollop et al. 2002). These are regulatory elements which determine sugar-specific gene expression responsiveness. It is possible that during the development of the PBD disorder, and although sugars are elevated by the time healthy plants are harvested (because of water loss), sugar is not being correctly transported through the phloem in the early steps of ripening, thus affecting anthocyanin synthesis and colour accumulation. Evidence supporting this idea is the anthocyanin accumulation found in the pedicels of PDB clusters. Since sugars are not able to advance to the berry, some may accumulate at the pedicel-brush junction and induce colour synthesis. 
A model explaining berry ripening in prematurely dehydrated clusters is presented in Figure 4. The onset of berry ripening begins with veraison and ends at the moment at which the maximum weight of the berry is reached. This is followed by a period of late-ripening during which the over-ripened berries suffer increasing water loss (McCarthy, 1999). Berries may exhibit this weight loss after the late stages of ripening as a consequence of a partial disconnection between the plant and the grape cluster. This disconnection is possibly facilitated by phytoplasma early in development, inducing necrosis at the end of the pedicel in the brush structure. Since this structure possesses all the vascular continuity to the berry, sugars are not transported, anthocyanins are poorly synthesised, acids are not degraded and water is lost.

Together with the occurrence of phytoplasma, environmental factors, the incidence of nematodes and agronomic management procedures, such as excessively restricted irrigation, may trigger PBD to different degrees. Since phytoplasmas were also present in plants without PBD symptoms, either these plants were in the initial stages of the disorder or climatic conditions and/or agronomic management had reduced their susceptibility to developing the disorder.

The fact that phytoplasmas were also detected in cv. Pinot noir raises the question as to whether this disorder is exclusive to cv. Merlot or whether it is already developing in other cultivars. In addition, the influence of agricultural practices and climatic conditions on phytoplasma incidence and the development of PBD needs to be addressed in future studies.

Although it was possible to correlate the incidence of phytoplasmas with the PBD-affected clusters, the PBD disorder may indeed be caused by several factors acting in a concerted manner. Developing diagnostic strategies and understanding the plant's response are crucial factors for optimizing agronomic management. In addition, direct effective control strategies need to be developed.

\section{ACKNOWLEDGMENTS}

We thank Dr Michael Handford for critically reading the manuscript.

\section{REFERENCES}

AHRENS, U. and SEEMULLER, N. Detection of DNA plat pathogenic mycoplasma by a polymerase chain reaction that amplifies a sequence of the 16SrRNA gene. Phytopathology, August 1992, vol. 82, no. 8, p. 828-832.

ANGELINI, E.; CLAIR, D.; BORGO, M.; BERTACCINI, A. and BOUDON-PADIEU, E. Flavescence dorée in France and Italy: occurrence of closely related phytoplasma isolates and their near relationships to Palatine grapevine yellows and an alder yellows phytoplasma. Vitis, 2001, vol. 40 , no. 2 , p. $79-86$.
AUSUBEL, F.M.; BRENT, R.; KINGSTON, R.E.; MOORE, D.D.; SEIDMAN, J.G.; SMITH, J.A. and STRUL, K. Current Protocols in Molecular Biology. $3^{\text {rd }}$ edition. New York; Green Publishing Associates and Wiley-Interscience, 1990, 233 p. ISSN 978-0-471-50338-5.

BORGO, M. and ANGELINI, E. Influence of grapevine leafroll (GLRaV3) on Merlot cv. grape production. Bulletin OIV, 2002, vol. 75 , no. 859, p. 611-622.

BOSS, P.K.; DAVIES, C. and ROBINSON, S.P. Analysis of the expression of anthocyanin pathway genes in developing Vitis vinifera L. cv. Shiraz grape berries and the implications for pathway regulation. Plant Physiology, August 1996, vol. 111, no. 4, p. 1059-1066.

BOUDON-PADIEU, Elisabeth. Grapevine phytoplasmas. In: First Internet Conference on Phytopatogenic Mollicutes. May 1999 [cited 10 June 2001]. Available from internet: http://www.uniud.it/phytoplasma/conf.html.

BOUDON-PADIEU, Elisabeth. The situation of grapevine yellows and current research directions: distribution, diversity, vectors, diffusion and control. In: MARTELLI G.P., ed. Proceedings of the $14^{\text {th }}$ Meeting of the International Council for the Study of Virus and Virus-like Diseases of the Grapevine (ICVG), Locorotondo (Bari), Italy, 2003, p. 47-53.

CABALEIRO, C.; SEGURA, A. and GARCIA-BERRIOS, J.J. Effects of grapevine leafroll-associated virus 3 on the physiology and must of Vitis vinifera L. cv. Albarino following contamination in the field. American Journal of Enology and Viticulture, March 1999, vol. 50, no. 1, p. 4044.

CHANG, Kan-Fa; HWANG, Sheau-Fang; KHADHAIR, Abdul-Hameed; KAWCHUK, Lawrence and HOWARD, Ronald. Detection and molecular characterization of an aster yellows phytoplasma in poker statice and Queen Anne's lace in Alberta, Canada. Microbiological Research, April 2004, vol. 159, no. 1, p. 43-50.

CHATELET, David; ROST, Thomas; SHACKEL, Kenneth and MATTHEWS, Mark. The peripheral xylem of grapevine (Vitis vinifera). 1. Structural integrity in postveraison berries. Journal of Experimental Botany, April 2008, vol. 59, no. 8, p. 1987-1996.

CHRISTENSEN, Nynne M.; NICOLAISEN, Mogens; HANSEN, Michael and SCHULZ, Alexander. Distribution of phytoplasmas in infected plants as revealed by real-time PCR and bioimaging. Molecular Plant-Microbe Interactions, November 2004, vol. 17, no. 11, p. 11751184.

CHRISTENSEN, Nynne M.; AXELSEN, Kristian B.; NICOLAISEN, Mogens and SCHULZ, Alexander. Phytoplasmas and their interactions with hosts. Trends in Plant Science, November 2005, vol. 10, no. 11, p. 526-535. 
DENG, Sujun and HIRUKI, Chuji. Amplification of $16 \mathrm{~S}$ rRNA genes from ulturable and nonculturable Mollicutes. Journal of Microbiology Methods, September 1991, vol. 14 , no. 1, p. 53-61.

EPSTEIN, M.A. and HOLT, S.J. The localization by electron microscopy of hela cell surface enzymes splitting adenosine triphosphate. The Journal of Cell Biology, November 1963, vol. 19, no. 2, p. 325-336.

GIBB, K.S.; PADOVAN, A.C. and MOGEN, B.D. Studies on sweet potato little-leaf phytoplasma detected in sweet potato and other plant species growing in Northern Australia. Phytopathology, February 1995, vol. 85, no. 2, p. 169-174.

GOLLOP, Rachel; FARHI, Sharon and PERL, Avihai. Regulation of the leucoanthocyanidin dioxygenase gene expression in Vitis vinifera. Plant Science, August 2001, vol. 161 , no. 3 , p. $579-588$.

GOLLOP, Rachel; EVEN, Sylvie; COLOVA-TSOLOVA, Violeta and PERL, Avihai. Expression of the grape dihydroflavonol reductase gene and analysis of its promoter region. Journal of Experimental Botany, June 2002, vol. 53, no. 373 , p. 1397-1409.

GREENSPAN, M.D.; SHACKEL, K.A. and MATTHEWS, M.A. Developmental changes in the diurnal water budget of the grape berry exposed to water deficits. Plant Cell and Environment, July 1994, vol. 17, no. 7, p. 811-820.

HERBERS, K.; TAKAHATA, Y.; MELZER, M.; Mock, H.P.; HAJIREZAEI, M. and SONNEWALD, U. Regulation of carbohydrate partitioning during the interaction of potato virus $\mathrm{Y}$ with tobacco. Molecular Plant Pathology, January 2000, vol. 1, no. 1, p. 51-59.

HERRERA, Guido and MADARIAGA, Monica. Immunological, microscopical and molecular evidence of phytoplasma in grapes. Agricultura Técnica, January 2003, vol. 63 , no. 1, p. 15-22.

HOFIUS, Daniel; HERBERS, Karin; MELZER, Michael; OMID, Ayelet; TACKE Eckhard; WOLF, Shmuel and SONNEWALD, Uwe. Evidence for expression leveldependent modulation of carbohydrate status and viral resistance by the potato leafroll virus movement protein in transgenic tobacco plants. The Plant Journal, December 2001, vol. 28 , no. 5 , p. 529-543.

KURTZ, Stefan; PHILLIPPY, Adam; DELCHER, Arthur L.; SMOOT, Michael; SHUMWAY, Martin; ANTONESCU, Corina and SALZBERG Steven L. Versatile and open software for comparing large genomes. Genome Biology, 2004, vol. 5, no. 2, p. R12.

LARTEY, Robert; GHOSHROY, Soumitra; HO, Joe and CITOVSKY, Vitaly. Movement and subcellular localization of a tobamovirus in Arabidopsis. Plant Journal, September 1997, vol. 12, no. 3, p. 537-545.

LEE, Ing-Ming; DAVIS, Robert E. and GUNDERSENRINDAL, Dawn E. Phytoplasma: Phytopathogenic mollicutes. Annual Review of Microbiology, October 2000, vol. 54, no. 1, p. 221-255.

LEE, Ing-Ming; MARTINI, Marta; MARCONE, Carmine and ZHU, Shifang F. Classification of phytoplasma strains in the elm yellows group $(16 \mathrm{SrV})$ and proposal of 'Candidatus Phytoplasma ulmi' for the phytoplasma associated with elm yellows. International Journal of Systematic and Evolutionary Microbiology, March 2004, vol. 54, no. 2, p. 337-347.

LORENZ, K-H.; SCHNEIDER, B.; AHRENS, U. and SEEMÜLLER, E. Detection of the apple proliferation and pear decline phytoplasmas by PCR amplification of ribosomal and nonribosomal DNA. Phytopathology, July 1995, vol. 85, no. 7, p. 771-776.

MANNINI, F.; GERBI, V. and CREDI, R. Heat-treated V. Virus-infected grapevine clones: agronomical and enological modifications. Acta Horticulturae (ISHS), September 1998, vol. 473, p. 155-164.

MARTINI, Marta; MURARI, Ermanno; MORI, Nicola and BERTACCINI, Assunta. Identification and epidemic distribution of two Flavescence doréerelated phytoplasmas in Veneto (Italy). Plant Disease, October 1999, vol. 83, no. 10, p. 925-930.

MCCARTHY, M.G. Weight loss from ripening berries of Shiraz grapevines (Vitis vinifera L. cv. Shiraz). Australian Journal of Grape and Wine Research, April 1999, vol. 5, no. 1 , p. 10-16.

MORENO, Y.; PARDO, C. and ORTEGA, S. Altered rootcanopy ratio and its effect on premature berry dehydration of own-rooted Merlot vines. In: ASEV $55^{\text {th }}$ Annual Meeting. $\left(30^{\text {th }}\right.$ June $-2^{\text {th }}$ July 2004, San Diego, California). American Journal of Enology and Viticulture, 2004, vol. 55, no. 3, p. 295A-323A.

O'BRIEN, T.P. and MCCULLY, M.E. The study of plant structure: principles and selected methods. Tharmarcarphi Pty., Ltd., Melbourne, MacMillan, 1981, p. 36-40.

REID, Karen; OLSSON, Niclas; SCHLOSSER, James; PENG, Fred and LUND, Steve. An optimized grapevine RNA isolation producere and stadistical determination of reference genes for real-time RT-PCR during berry development. BMC Plant Biology, 2006, vol. 6, p. 27-37.

REYNOLDS, Edwards S. The use of lead citrate at high $\mathrm{pH}$ as an electron-opaque stain in electron microscopy. Journal of Cellular Biology, April 1963, vol. 17, no. 1, p. 208-212. 
ROGIERS, Suzy Y.; HATFIELD, Jo M.; JAUDZEMS, V. Gunta; WHITE, Rosemary G. and KELLER, Markus. Grape Berry cv. Shiraz Epicuticular Wax and Transpiration during Ripening and Preharvest Weight Loss. American Journal of Enology and Viticulture, June 2004, vol. 55, no. 2, p. 121-127.

RUDZINSKA-LANGWALD, A. and KAMINSKA, M. Cytopathological evidence for transport of phytoplasma in infected plants. Acta Societatis Botanicorum Poloniae, 1999, vol. 68, p. 261-266.

SCHNEIDER, B.; SEEMÜLLER, E.; SMART, C.D. and KIRKPATRICK, B.C. Phylogenetic classification of plant pathogenic mycoplasmalike organisms or phytoplasmas. In: RAZIN, S. and TULL, J.G. eds. Molecular and Diagnostic Procedures in Mycoplasmology, San Diego, CA, Academic Press, 1995, vol. 1, p. 369-380.

SIDDIQUE，A.B.M.; GUTHRIE，J.N.; WALSH，K.B.; WHITE, D.T. and SCOTT, P.T. Histopathology and within-plant distribution of the phytoplasma associated with Australian papaya dieback. Plant Disease, October 1998, vol. 82 , no. 10 , p. 1112-1120.

TYERMAN, S.D.; TILBROOK, J.; PARDO, C.; KOTULA, L.; SULLIVAN, W. and STEUDLE, E. Direct measurement of hydraulic properties in developing berries of Vitis vinifera L. cv Shiraz and Chardonnay. Australian Journal of Grape and Wine Research, October 2004, vol. 10 , no. 3, p. 170-181.

VITRAC, Xavier; LARRONDE, Fabienne; KRISA, Stéphanie; DECENDIT, Alain; DEFFIEUX, Gérard and MÉRILLON, Jean-Michel. Sugar sensing and $\mathrm{Ca} 2+-$ calmodulin requirement in Vitis vinifera cells producing anthocyanins. Phytochemestry, March 2000, vol. 53, no. 6, p. 659-665. 